\title{
Development of Information and Technology-based Learning Media in Athletic Materials for Short Distance Running Numbers for Quality Junior N 2 Students in Lubuk Linggau City, South Sumatra Province
}

\author{
Nurul Ihsan*, Khodijah Reza Amum, Willadi Rasyid, Hendri Neldi \\ Faculty of Sport Science, Padang State University, Padang, 25131, West Sumatra, Indonesia \\ Received September 22, 2020; Revised January 18, 2021; Accepted January 26, 2021
}

\begin{abstract}
Cite This Paper in the following Citation Styles
(a): [1] Nurul Ihsan, Khodijah Reza Amum, Willadi Rasyid, Hendri Neldi, "Development of Information and Technology-based Learning Media in Athletic Materials for Short Distance Running Numbers for Quality Junior N 2 Students in Lubuk Linggau City, South Sumatra Province," International Journal of Human Movement and Sports Sciences, Vol. 9, No. 1, pp. 124-129, 2021. DOI: 10.13189/saj.2021.090117.
\end{abstract}

(b): Nurul Ihsan, Khodijah Reza Amum, Willadi Rasyid, Hendri Neldi (2021). Development of Information and Technology-based Learning Media in Athletic Materials for Short Distance Running Numbers for Quality Junior N 2 Students in Lubuk Linggau City, South Sumatra Province. International Journal of Human Movement and Sports Sciences, 9(1), 124-129. DOI: 10.13189/saj.2021.090117.

Copyright $\bigcirc 2021$ by authors, all rights reserved. Authors agree that this article remains permanently open access under the terms of the Creative Commons Attribution License 4.0 International License

\begin{abstract}
The athletic learning process in short distance running numbers at SMP Negeri 2 Quality in Lubuklinggau City, South Sumatra Province, has low learning outcomes in the aspect of knowledge, because it has not utilized information technology-based learning media and the learning needs of Physical Education in schools have not been fulfilled completely. The purpose of this study is to develop information technology-based learning media on athletic material for short distance running numbers for students and to determine the increase in learning outcomes before and after using the media. This study uses a development method with a model design adapted from Borg \& Gall. The subjects of this study were students of SMP Negeri 2 Lubuklinggau City, South Sumatra Province, totaling 15 people from each class level, and three experts, namely one media or teaching materials expert and two athletic material experts. The learning media development process is carried out through a modular test stage which is packaged in an application that contains a description of the material accompanied by pictures and video tutorials. Then the validation test was carried out with the help of instructional media experts and inget a percentage of $88.89 \%$ in the Very Appropriate category from the media expert's assessment, while in terms of the learning material
\end{abstract}

provided by the first material expert, the results are $86.42 \%$ in the Very Appropriate category and the second material expert's assessment results in the amount of $97.15 \%$ are in the Very Appropriate category to use and will attract students and make it easier for students to imitate the movements they have seen and indirectly shorten the time in learning the movements. In addition, there is an increase in learning outcomes before and after the use of instructional media that has been given. This study uses a development method with a model design adapted from Borg \& Gall.

Keywords Media Development, Information Technology, Short Distance Running

\section{Introduction}

Sports in Indonesia already has a legal umbrella, namely RI Law no. 3 of 2005 concerning the National Sports System, Sports are all systematic activities to encourage, foster and develop physical, spiritual and social potential. Athletics is the oldest sport that has been 
carried out by humans since ancient times until now. Athletics is a physical activity or physical exercise that contains natural and natural movements according to what is done in our daily lives, like walking, running, jumping, throwing and jumping.

Learning media in the teaching and learning process can arouse desire and interest in learning, generate motivation and stimulation of learning activities, and even bring psychological influences on students. [1] "Learning Media is a set of tools or supplements used by teachers in order to communicate with students". Learning media includes a very strategic means for teachers to transfer knowledge to students, so that the existence of learning media can spur students to use more of their senses than if the teacher only provides verbal information as is usually done which will ultimately arouse desire and interest in learning, generate motivation and stimulation of learning activities.

Learning activities are a series of activities in which there is a process of interaction between students and learning resources, but the learning process that takes place is in fact mostly still centered on educators, not on visual learning media such as video learning for the athletic branch of short distance running numbers which are able to provide stimulus to students. to respond to fun and more innovative Physical Education learning. With the existence of a fun and innovative learning atmosphere, it is hoped that it can increase the motivation of students to complete Physical Education learning. Ideally quality learning can help and facilitate students to develop their potential optimally, and be able to achieve the set goals effectively, which are oriented towards their interests, needs, and students' abilities which in the process are identified with the process of delivering information or communication, in this case the learning media. Learning media is an inseparable part, so it is necessary to develop media so that the learning process that occurs is in accordance with the needs and learning objectives expected.

The availability of learning media for physical education lessons is widely available on the internet, either in printed or visual form. However, sometimes in the form of material that is balanced with pictures and video tutorials that explain in detail and according to the needs of physical education lessons in schools, they have not been completely fulfilled. Some of them already exist, such as those contained in the 2013 curriculum teacher learning book, which contains several examples in the form of pictures. The advantages of this book are that it can be downloaded for free and minimizes paper usage,

One of the ways to develop learning media is to use information technology-based media or Information Technology (IT). Information technology-based learning media is learning by producing or delivering material using micro-processor-based sources. The difference between other media is that information or material is stored in digital form, not in printed or visual form. Basically, technology is based on information technology in presenting material to students using a glass screen. Various types of media for computer-based technology in learning are generally known as computer-assisted learning.

Based on the results of observations found in the field that the physical education learning process at SMP Negeri 2 Quality in Lubuklinggau City, South Sumatra Province, the learning outcomes of students are still low due to the lack of use of existing learning media and facilities, such as multimedia rooms that can be used for teaching and learning using learning media based on information technology so that students do not feel bored with learning activities carried out continuously in the field, students only know practical movements and do not know the theory in athletic learning materials for distance running numbers, and physical education teachers are also still less creative in modifying learning and do not pay attention to the movements made by students and do not re-evaluate what students have done in the teaching and learning process movement.

To overcome the boredom experienced by students, teachers can use information technology-based learning methods so that students can stimulate the brain and generate interest in running short distances because the learning methods used have required students to be more active, and seek information using information technology-based media. In this information technology-based learning model, the teacher provides material in the form of videos and photos of short-distance running movements as a simulation of movements that will be practiced in the field.

Based on the above problems, the authors are interested in developing information technology-based learning media on athletic material for short distance running numbers so that students can observe athletic movements that can be repeated using visualizations that contain a series of material in the form of images accompanied by athletic video tutorials. at SMP Negeri 2 Quality in Lubuklinggau City, South Sumatra Province, because of the findings it is known that the athletic learning process at SMP Negeri 2 Quality in Lubuklinggau City, South Sumatra Province is still not utilizing information technology-based learning media as evidenced by the absence of the media used in the implementation plan learning owned by the teacher.

The author only takes the athletic material for the short distance running number, because the short distance running number is found in the student worksheet (LKS) and the field used does not require using the actual running field, but can be modified the facilities and pre-facilities such as using an empty field at school because At SMPN 2 Quality, Lubuklinggau City, South Sumatra Province has an adequate field or can be used in the physical education teaching and learning process. And 
also most importantly this short distance running number is in the curriculum of physical education subjects in junior high schools.

The purpose of this study was to develop information technology-based learning media and to determine the increase in student learning outcomes before and after using information and technology-based learning media on athletic material for short-distance running numbers of students at SMP Negeri 2 Qualified, Lubuk Linggau City, South Sumatra Province.

\section{Materials and Methods}

This research method is research and development (Research and Development). Research and Development research methods are methods used to produce certain products or improve existing products, and test the effectiveness of the product (Sugiyono, 2012). This study aims to develop information technology-based learning media. In addition, this study aims to produce efficient learning media by utilizing the Macromedia Flash Professional 8 application which is packaged in the form of video [3]. This research was conducted at SMP Negeri 2 Quality Lubuklinggau City, South Sumatra Province, which is located on Jalan Letkol Sukirno, Lubuklinggau Timur 1 District, Lubuklinggau City, South Sumatra Province through the WhatsApp group. When the research was conducted in August 2020, the subjects of the research were 15 students of SMP Negeri 2 Quality in Lubuklinggau City, South Sumatra Province, consisting of five class VII students, five class VIII students, and five class IX students as small group test students, three experts as product test experts, namely one media expert or teaching materials expert and two athletic material experts in sprinting numbers. At the product testing stage, it was carried out with lecturers who were teaching media courses and athletic material experts. Three experts are product testing experts, namely one media or teaching material expert and two athletic material experts for short distance running numbers. At the product testing stage, it was carried out with lecturers who were teaching media courses and athletic material experts, three experts as product testing experts, namely one media or teaching material expert and two athletic material experts for short distance running. At the product testing stage, it was carried out with lecturers who were teaching media courses and athletic material experts.

In this study, researchers used a research and development model from Borg and Gall which suggests research and development steps consisting of ten steps, namely problems, data collection, product design, design validation, design revision, product testing, product revision, testing. Try usage, product revision, and mass production.

Data collection uses learning materials which include reference books and preparing learning media for athletic objects in the form of images and videos, and in this study data collection uses open and closed questionnaires to collect data used in the trial phase. An open questionnaire will be used to collect data about criticism and suggestions from expert experts, while a closed questionnaire is used for the evaluation of IT-based learning media and uses a Likert scale that will involve students from three class levels.

The data analysis in this study used the media feasibility percentage from the questionnaire data that had been obtained. The percentage of eligibility of the media can use a systematic calculation formula as follows:

Persentase kelayakan $(\%)=\frac{\text { Skor yang diporeh }}{\text { Skor yang diharapkan }} \times 100 \%$

The results of these calculations are then used to determine the feasibility of the media or products produced using the category ranges contained in table 1 .

Table 1. Eligibility Categories

\begin{tabular}{|c|c|}
\hline Interval & Score \\
\hline $81 \%-100 \%$ & Very Eligible \\
\hline $61 \%-80 \%$ & Eligible \\
\hline $41 \%-60 \%$ & Fairly feasible \\
\hline $21 \%-40 \%$ & Not Eligible \\
\hline$<21 \%$ & Very Unfeasible \\
\hline
\end{tabular}

(Source: Sugiyono, 2012)

The analysis of the improvement in learning outcomes for the development of learning media was carried out by exercising the questions given to the pretest-posttest students who were analyzed using the t-test using the SPSS version 25 program.

\section{Results and Discussion}

From the research that has been conducted by researchers and the feasibility test of the learning media developed in this study, it is compiled through the stages of the modular test process by researchers and examination by experts, validation by media experts shows the feasibility percentage of learning media is at the level of $88.89 \%$ which means learning media is very feasible to use. The first material expert shows the feasibility of learning media at the level of $86.42 \%$ which means that the learning media is very feasible to use and needs to be revised. Meanwhile, the second material expert shows the feasibility percentage of learning media is at the level of $97.15 \%$ which means that the learning media is very feasible to use and does not need to be revised.

The product of the development of this learning media is in the form of information technology-based learning media made using Macromedia Flash Professional 8 with 
several considerations, namely that this program is very effective in using online learning conditions as it is today, this program is easier to use, can display multimedia programs, and is an interactive learning media that is easier if it will be developed again by teachers to be modified into other materials.

Information technology-based learning media used in this study contain related menus with athletic lessons in sprint numbers. This learning media has done and practiced in each class at the Quality Middle School 2 in Lubuklinggau City, South Sumatra Province. Each validation test results development of based learning media information Technology on the athletic material of the sprint number this has been validated by media and materials experts.

The results of the validation of the media and material experts provide advice and provide an assessment of the resulting learning media so that the resulting learning media can be used in the field or not. The results of the media expert's validation test assessed the content of the material which consisted of technical aspects consisting of readability, ease, quality of appearance and impressions, then the display aspects consisted of visibility, natural and logical, control, consistency, easy to recognize, and quality of documentation. Whereas material experts assess the content of the media which consists of aspects of material quality which include determination, importance, completeness, material adequacy with the situation of students, then aspects of learning quality which consist of learning opportunities, providing learning assistance, learning flexibility, relationships with other teaching programs, impact on students, and the impact on teachers and learning. Based on the results of data analysis, it was found that the media expert's assessment was in the Very Appropriate category. Meanwhile, from the results of the expert's assessment, the material is in the Very Appropriate category. Referring to the category of the results of the assessment of the three experts, thenbased learning media information Technology on the athletic material of the sprint number This is declared valid and very feasible to be used as an information technology-based learning media in the Athletic Material of the Short Distance Running Number for Junior High School level, especially in SMP Negeri 2 Quality, Lubuklinggau City, South Sumatra Province.

Based on the product of the results development of information technology-based learning media on athletic material for short distance running numbers, it can be seen that the characteristic of the teaching media used in the learning process is the combination of pictures and video tutorials athletics sprint number which is arranged in accordance with the 2013 curriculum. This teaching media also contains material core competencies athletics sprint number which is accompanied by an explanation of the material by integrating various types of media such as music, pictures, videos, and animated text.
Based on the results pre-test and post-test evaluation of athletic learning with short distance running numbers through the use of information technology-based learning media products that have been developed, it is found that there are differences in student learning outcomes before and after using the development of information technology-based learning media that the authors have developed.

So it can be concluded that by using based learning media information technology, then the learning process from home due to the COVID-19 pandemic is very effective for use in the learning process. Judging from the results of research conducted that there is an increase in the results of learning evaluation of students before and after using based learning media, information technology that has been developed.

The analysis of the improvement of student learning outcomes using the development of learning media was carried out using the $t$ test using the SPSS 25.0 program. The following are the results of the pre-test and post-test evaluation of athletic learning for the short distance running numbers listed in the following table:

Table 2. Students' Responses to Athletic Learning Media Development Products on Short Distance Running Numbers

\begin{tabular}{|c|c|c|c|c|}
\hline No & Respondent & Class & Pre-test & Post-test \\
\hline 1 & Student 1 & VII & 9 & 10 \\
\hline 2 & Student 2 & VII & 5 & 10 \\
\hline 3 & Student 3 & VII & 2 & 5 \\
\hline 4 & Student 4 & VII & 3 & 10 \\
\hline 5 & Student 5 & VII & 7 & 10 \\
\hline 6 & Student 6 & VIII & 10 & 10 \\
\hline 7 & Student 7 & VIII & 3 & 9 \\
\hline 8 & Student 8 & VIII & 8 & 9 \\
\hline 9 & Student 9 & VIII & 4 & 10 \\
\hline 10 & Student 10 & VIII & 4 & 10 \\
\hline 11 & Student 11 & IX & 3 & 8 \\
\hline 12 & Student 12 & IX & 7 & 10 \\
\hline 13 & Student 13 & IX & 6 & 10 \\
\hline 14 & Student 14 & IX & 6 & 10 \\
\hline 15 & Student 15 & IX & 5 & 10 \\
\hline
\end{tabular}

Information:

(1) In the Paired Sampels table, it can be seen that the average results of the evaluation of the use of information technology-based learning media in students before being given learning media are 5.47 and a standard deviation of 2.386 and after being given learning media the results are 9.40 and a standard deviation of 1.352. This means that descriptively there are differences in the average learning outcomes using information technology-based learning media before and after 
being given information technology-based learning media on athletic material for short distance running numbers.

(2) In the Paired Samples Correlations table, it is found that the correlation coefficient of learning outcomes using information technology-based media between before and after being given learning media is 0.491 with the number sig. or $p$-value $=0.063 \geq 0.05$, it means that it is significant.

(3) In the Paired Samples Test table, the difference in Mean $=3,933$ is obtained, which means the difference in learning outcomes using information technology-based learning media between after and before being given learning media. And the most important result from this table is the statistical price $t$ $=7,302$, with $\mathrm{db}=14$ and the number sig. or $\mathrm{p}$-value $=$ $0.000<0.05$ or Ho is rejected.

The improvement of learning outcomes before and after using Information Technology-based learning media on athletic material for short distance running for quality SMP N 2 students in Lubuklinggau City, South Sumatra Province can be seen from the statistical test in the table below:

Table 2. SPSS Output Results for Average Media Usage

\begin{tabular}{|c|c|c|c|c|c|}
\hline \multicolumn{6}{|c|}{ Paired Samples Statistics } \\
\hline \multicolumn{2}{|c|}{} & Mean & N & Std. Deviation & $\begin{array}{c}\text { Std. Mean } \\
\text { Error }\end{array}$ \\
\hline \multirow{2}{*}{ Pair 1 } & Before & 5.47 & 15 & 2,386 & .616 \\
\cline { 2 - 6 } & After & 9.40 & 15 & 1,352 & .349 \\
\hline
\end{tabular}

Table 3. SPSS Output Score Correlation Coefficient

\begin{tabular}{|c|c|c|c|c|}
\hline \multicolumn{5}{|c|}{ Paired Samples Correlations } \\
\hline \multicolumn{2}{|c|}{} & $\mathrm{N}$ & Correlation & Sig. \\
\hline Pair 1 & Before after & 15 & .491 & .063 \\
\hline
\end{tabular}

Table 4. Results of Differences Before and After Media Use

\begin{tabular}{|c|c|c|c|c|c|c|c|c|c|}
\hline \multicolumn{10}{|c|}{ Paired Samples Test } \\
\hline & & \multicolumn{5}{|c|}{ Paired Differences } & \multirow{3}{*}{$\mathrm{t}$} & \multirow{3}{*}{ df } & \multirow{3}{*}{$\begin{array}{c}\text { Sig. } \\
(2 \text {-tailed })\end{array}$} \\
\hline & & \multirow{2}{*}{ Mean } & \multirow{2}{*}{$\begin{array}{c}\text { Std. } \\
\text { Deviation }\end{array}$} & \multirow{2}{*}{$\begin{array}{l}\text { Std. Error } \\
\text { Mean }\end{array}$} & \multicolumn{2}{|c|}{$\begin{array}{l}\text { 95\% Confidence Interval of the } \\
\text { Difference }\end{array}$} & & & \\
\hline & & & & & Lower & Upper & & & \\
\hline Pair 1 & $\begin{array}{l}\text { Sesudah - } \\
\text { Sebelum }\end{array}$ & 3.933 & 2.086 & .539 & 2.778 & 5.089 & 7.302 & 14 & .000 \\
\hline
\end{tabular}


From the tables, it can be seen that there is a significant increase in learning outcomes using information technology-based learning media before and after being given information technology-based learning media on athletic material for short distance running numbers.

Based on the results of data processing and analysis of the research data that has been done, regarding development of learning media based on information technology in the material athletics sprint number This student of SMP Negeri 2 Quality Lubuklinggau City, South Sumatra Province obtained the following conclusions:

(1) With the state of the Covid-19 pandemic like at this time the process of developing information technology-based learning media really helps teachers in the teaching and learning process, because schools do not allow face-to-face so that teachers are required to be more creative in providing materials effectively through information technology-based learning media. Researchers make learning media on the material athletics sprint number. The students of Quality Middle School 2 in the City of Lubuklinggau were carried out through the stages of a needs analysis in the Physical Education subject at SMP Negeri 2 Quality in Lubuklinggau City. Learning media development products based on information technology in the materialathletics sprint number packaged in a folder containing a description of the material accompanied by pictures and video tutorials. After going through the modular test stage, the researcher carried out the validation test stage with the help of an expert, namely a media expert by Ms. Novrianti, M. Pd., as a lecturer at Padang State University who served as a Lecturer at the Educational Technology Study Program, Faculty of Education, Padang State University with a percentage of $88.89 \%$. Mr. Dr. material expert Ardo Okilanda, M.Pd. as a Lecturer at the PGRI Palembang University who served as a Lecturer in the Physical Education Study Program of the FKIP PGRI Palembang with a percentage of $86.42 \%$. As well as the second material expert, Ms. Vollyanti Reza Amum S. Pd, as a physical education teacher at the Quality Middle School 2 in Lubuklinggau City, South Sumatra Province, with a percentage of $97.15 \%$. Then after making some revisions to the experts, the products that are made are ready to be tested on students.

(2) After a small group trial test was carried out on students, there was an increase in learning outcomes after students were given material in the form of video-based learning information technology. So the learning process carried out through learning media is said to be effective because the information messages contained in the media reach students.
(3) The implication of this learning media is the results of this study can have positive implications for various parties involved in this research, especially for education providers. The use of information technology-based learning media for Physical Education subjects at SMPN 2 Quality in Lubuklinggau City, South Sumatra Province as a means of teachers in physical education learning which can be one way to motivate and improve student learning outcomes.

(4) The learning materials and activities presented in this media make it easier for teachers to deliver learning materials that will be implemented to students, increase students' knowledge, so that they can have a positive influence on students' learning outcomes.

\section{REFERENCES}

[1] Alnedral, (2015), Strategi Pembelajaran PJOK. Yogyakarta: CV. ANDI OFFSET (penerbit ANDI Anggota IKAPI)

[2] Damin, S. (2013). Media Komunikasi Pendidikan. Jakarta: Bumi Aksara.

[3] Kurniawan, F. (2012). Buku Pintar Pengetahuan Olahraga. Jakarta: Laskar Aksara.

[4] Munir, (2010), Kurikulum Berbasis Teknologi Informasi Dan Komunikasi. Bandung: Alfabeta.

[5] Priyanto, D. (2009). Pengembangan Multimedia Pembelajaran Berbasis Komputer. Jurnal Pemikiran alternative Kependidikan. Vol. 14. No. 1. 92-110.

[6] Rusman, Kurniawan, D, dan Riana, C. (2011). Pembelajaran Berbasis Teknologi Dan Komunikasi. Jakarta: Raja Grafindo Persada

[7] Sanjaya, W. (2011), Perancanaan dan Desain Sistem Pembelajaran. Jakarta: kencana.

[8] Sidik, D.Z. (2011). Mengajar dan Melatih Atletik. Bandung: PT. Remaja Rosdakarya.

[9] Suartama, I.K. (2010). Pengembangan Mutimedia Untuk Meningkatkan Kualitas Pembelajaran Pada Mata Kuliah Media Pembelajaran. Jurnal Pendidikan dan Pengajaran, Jilid 43, Nomor 3, Oktober 2010.253-262

[10] Sugiyono, (2017). Metode Penelitian Pendidikan Pendekatan Kuantitatif, Kualitatif, dan $R \& D$. Bandung: Alfabeta.

[11] Sugiyono, (2012). Metode Penelitian Pendidikan Pendekatan Kuantitatif, Kualitatif, dan $R \& D$. Bandung: Alfabeta.

[12] Suryani, N (2015) Pengembangan Media Pembelajaran Sejarah Berbasis IT. Jurnal Sejarah dan Budaya. Vol. 10. No. 2. 186-195. 